\title{
Parental Communication Patterns and Children's Christmas Requests
}

This article is dedicated to the memory of Dr Tino Oresti Fenech who passed away in October,

2007. Tino was a visionary in E-commerce; he had a passion for both marketing and teaching that he shared freely with students and colleagues alike: A good friend.

\section{Author}

\section{Peter Clarke}

Is a lecturer at Griffith University in the Department of Marketing. His research interests focus on Christmas, gift giving and consumer behavior. Publications appear in the Journal of Consumer Behavior and Journal of Consumer Marketing and he has delivered papers on consumer behavior at national and international conferences.

Address all Correspondence to:

Dr. Peter Clarke

Department of Marketing

Griffith Business School

Griffith University, Nathan Campus

170 Kessels Road

NATHAN QLD 4111

Phone: +61 737357352

Fax: $\quad+61737357126$

Email: p.clarke@griffith.edu.au 


\title{
Parental Communication Patterns and Children's Christmas Requests
}

\author{
Abstract \\ Purpose - An important part of the Christmas ritual is the request tradition. Parents ask their \\ children what they would like for Christmas, respond to a child's request or often initiate such \\ Christmas communication exchanges. These styles of family communication relates to the \\ socialization of children into consumption and Christmas. This exploratory study considers aspects \\ of parental approaches to their children's request behavior within the Family Communication \\ Patterns (FCP) typology.
}

Design/methodology/approach - Data gathered via a survey of parents in the period prior to Christmas supported the factor structure of the FCP typology via Exploratory Factor Analysis and Confirmatory Factor Analysis.

Findings - It appears that parents encourage a positive exchange of desire and opinion from children; they also question the sources of information and suitability of the gift. In this manner, parents appear to condone, if not generate, an atmosphere of open request behaviour because the limiting of gift requests through direct parental instruction is minimal.

Practical implications - Continual adaptation of the FCP typology from the original context has implications for consumer behaviour theory at a factor analysis level. Parental responses to Christmas request behaviour is an important topic of interest to consumer behavior researchers, the toy industry, retailers and business in general.

Originality/value - This research explores contemporary issues of parental interactions with their children during the gift request ritual. It is timely to explore theory related to this topic because much of the rhetoric around Christmas accentuates the pester power syndrome. Yet, Christmas symbolizes love, family and nurture where parental values engender request behaviour and children's desires generate the requests. The findings have consequences for consumer advocates 
and social commentators, as well as providing cultural and ritual interpretations within parent child interactions.

Keywords - Parents, Christmas requests, Family communication,

Paper type - Research paper

\section{Introduction}

The concept of holiday season gift exchanges around December features gift giving activities between friends and within family, however, the ritual of the season highlights the child oriented enchantment of Santa and of children receiving presents. Toys continue to be one of the top choices for children's Christmas gift requests and current annual sales of toys are around \$US21.3 billion (The NPD Group Inc, 2006). Otnes et al. (1994) suggest that nearly all of the advertising expenditures for the most popularly requested toys occur in the September quarter. Therefore, if the level of consumer spending is a measure of Christmas activity (Belk, 1987), then the Christmas period is an important occasion, not just for business, nor those making purchases to give as gifts, but also for those requesting gifts.

Christmas is an occasion that highlights, socializes and condones request behavior in children that is exemplified by all those letters of request written to Santa. While a parent may, or may not honor a child's decision about their preferred Christmas gift, the child is generally empowered to make the decision about what they would like for Christmas. A critical component of request behavior is the response by parents to their children's requests. In essence, the request may incur an open, twoway exploration of possibilities and choice, but the final preference decision is with the child. On the other hand, there may be a one-way exchange that restricts or prohibits choices and enforces rules or conditions related to Christmas gifts and requests. In addition, parents may openly question any suggestions or requests offered and children would have to defend their choices. 
Parents attempt to socialize children into cultural and consumer practices that align with parental values; and studies in the literature refer to the parental responses of encouraging or admonishing the acquisition of social and consumer skills in their children (Carlson et al., 1994). Hill and Romm (1996) indicate family or promotional influences moderate the gift selection process. If parents talk with, and guide their children in such areas as advertising and marketplace activities, then there is an identified gap in the literature regarding family communication within the Christmas request ritual.

\section{Children's Christmas Requests and Parental Reaction}

While the sociological view of Christmas ritual has received attention (eg Belk, 1987, Caplow, 1984), there is minimal exploration of the parent-child interactions from a marketing perspective. Sherry (1983) identifies the input of the recipient as being essential to a successful gift exchange and calls for research into this phenomenon; as such recipients employ a guidance strategy that incorporates hints, requests, barter or nonverbal ploys. Such requests have an impact on the givers external and internal search for the actual item and a place of purchase. External searches cover the style or type of gift that is appropriate for the occasion, while internal searches rely on the giver's own values, ideas or knowledge. Parents encourage and respond to gift requests from their children because request behavior is an integral part of the Christmas gift giving tradition.

Importantly, writing letters to Santa socialize children into the world of Christmas receiving because children write to request items desired as gifts. To date, research about children's Christmas request behavior is generally through letters written to Santa (Caron and Ward, 1975, Downs, 1983, O'Cass and Clarke, 2002, Otnes et al., 1994, Richardson and Simpson, 1982). These letters to Santa allow children to express their desires, without question, to nominate or suggest what they want for Christmas. In this way, requests become a major source of information for parents about possible gifts because, as Clark (1995) indicates, the content of letters to Santa are taken seriously. Such requests include brands as well as product categories. Common phrases are "please bring me", "can I have"; or "will you get me", as well as semantic phrases such as "I have 
been good" support their written or verbal requests for gifts at Christmas (O'Cass and Clarke, 2002, Otnes et al., 1994). Letters to Santa indicate children's use of brands through illustrations or catalogue cut-outs that contain product and brand illustrations or prices (O'Cass and Clarke, 2002). An examination of letters written to Santa (Clarke, 1998) reveals three different categories. Firstly, there are Children's Letters identified as written solely by either a boy or girl; the second is a Partnership Letter where there is evidence of a parent writing the letter, together with the child who assists or illustrates the letter in an approximate equal sharing. Thirdly, there are Adult Letters where an adult appears to write the entire letter on behalf of the child with phrases such as "my name is Tom and I am 3 years old". Of the 725 letters analyzed, children wrote 422 letters requesting an average of 4.2 gifts, of which 1.9 were brand name items; 82 partnership letters averaged 3.9 gifts and 1.2 brands; 221 adult authored letters held an average of 2.9 gifts and 0.9 brands. The authorship span indicates a decline in the numbers of both gifts and brands as the parental participation in the ritual increases. In addition, these studies indicate that children have a strong awareness of the diversity of brand name goods available to them, are able to specify preferences between brands and have the knowledge to use brand names and brand extensions in their request behavior.

Parental reaction to children's requests tends to support these observations. Caron and Ward (1975) suggest that parents react positively to children's Christmas requests about $30 \%$ of the time, negatively about $20 \%$ and were neutral or put off any commitment either way around $50 \%$ of the time. Responding positively only $30 \%$ of the time suggests that parents are unsure about the gift they will give and continue to gather ideas for gifts or wait until the child decides on a gift that they really prefer. One-third approval may also mean that children request more items than what parents are willing to give as gifts. Isler et al. (1987) reported similar responses and indicated a "stall or substitute" response category which included the parent saying yes to the product category but not to the brand the child requested, saying no but agreeing to buy something else instead, or by saying maybe sometime but not now. On the other hand, they may not discuss these gift requests in depth 
because parents try to maintain an element of surprise. Overall, it seems that mothers talk more about the time, effort and sacrifices to respond to such requests (Hill and Romm, 1996).

\section{Marketplace Communication}

A psychological approach to family communication incorporates the topics of children's behavior, parental styles and expectations about children's social behavior (Baumrind, 1968, Becker, 1964). Within the family context, child development means participation in social and economic systems where dyadic interactions exist between a child and their siblings, parents or the extended family Grotevant, 1989). The theories and models of (Baumrind (1989) and Becker (1964) argue that the emotional input of parents and their latitude of control, predict specific aspects of discipline and development. Maternal references to feelings, rules and consequences of the child's actions relate to early conscience development in children (Laible and Thompson, 2000). Such references entailed positive use of praise and reasoning or negative methods such as showing disappointment or withdrawing love (Becker, 1964).

An early study on political socialization (McLeod and O'Keefe, 1972) forms the basis of the development of marketing theory in a family communication context which concentrates on communication or socialization activities in terms of parental actions or reactions (Carlson et al., 1990, Carlson et al., 1994). There are four family types within the FCP typology. The first is the Pluralistic family who emphasize the development of strong, yet varied concept-relations, however, they do not insist on obedience to authority and the child is encouraged to explore new ideas and to express them without fear of retaliation. The second is the Consensual family who stress agreement through both types of orientations and the child faces the incompatible situation that encourages exploration of controversy and the development of autonomous views yet; children must still adhere to parental ideas and control. The third type is the Protective family who stress the importance of obedience and social harmony between parents and child. Ultimately, they seek family order and give no autonomy in consumer activities. The fourth style of laissez faire family means there is no parental encouragement of deference, or of consumer abilities in their children. 
The type of communication exemplified by the Family Communication Patterns (FCP) measure is responsive; that is, the parent anticipates or responds to the child's behavior, with some form of encouragement or admonishment (Tims and Masland, 1985). Marketplace communication theory maintains that the family is instrumental in teaching children about consumption (Carlson et al., 1990, McLeod and O'Keefe, 1972, Palan, 1998) through overt and nonverbal patterns of interaction between parents and children (Carlson and Grossbart, 1988 ). Although research has examined mothers and fathers communication (Kim and Lee, 1997), the majority of communication and socialization studies are predominantly mothers' activities (Carlson et al., 1990, Carlson et al., 1994). These activities cover lecturing on consumer activities, discussing consumer decisions, setting examples or allowing the child to learn through experience.

According to Carlson et al. (1994), mothers' materialistic and shopping tendencies, advertising attitudes, information use, and consumption motivations are linked to FCP. It appears that both parents and children acquire information from outside the family through avenues such as the mass media and bring this information to family communication discussions. Irrespective of the low power that the child exerts on a parent, communication is a two-way avenue to generate consumer behavior thoughts and practices in either children or adults. It can be a reciprocal process (Ekstrom et al., 1987), or one where children act as change agents (Easterling et al., 1995). Hence, it appears that children are instrumental in alerting parents to the existence of various products and brands available in general or specific product categories.

\section{Christmas communication}

In western style consumption, parents socialize and encourage hedonic consumption of goods or services by their children at Christmas (Clark, 1995, Belk, 1989, Gunter and Furnham, 1998, Pollay, 1987). In essence, parents, and the extended family, use the veneer of Santa Claus to encourage children to gather information, express preferences and make choice decisions. At a simple and uncomplicated level of fun, children easily learn a consumer process that is similar to 
adult consumption practices, but does not incorporate the more serious and realistic variables such as financial and purchase considerations.

Parents appear to use a number of avenues to encourage request behavior or they nominate the style, type, product or brand they feel is suitable as a gift. Since requests are an exchange of ideas or preferences, the way parents communicate with their children about Christmas and consumption can be a creative and positive exchange, or an opportunity to exercise restrictive parental control through directions and rules. Through family communication and socialization, parents instill their values and views of how they want their children to understand, interpret and interact within a commercial world (Carlson et al., 1990).

Although the literature has a focus on a child's influence within the decision process, children may have an impact on purchase decisions through either influence or a request. Lackman and Lanasa, (1993) describe influence, as an offer of an opinion; while a request is a statement of preference (Isler et al., 1987 9). Many children appear to influence household purchase decisions that vary from food, clothing, confectionery and cereal (Roberts et al., 1981) to music, computers, television, magazines, family motor vehicles (Foxman et al., 1989) and outings (Labrecque and Ricard, 2001). However, young children simply ask for products (Isler et al., 1987), while older children offer product and brand knowledge about their gift preferences in a two-way exchange with parents. These complex interactions of family communication patterns distil into a two-dimension, communication pattern of concept and socio-orientation. The concept-orientation expects the child to develop social skills and their own views about the world, while a socio-orientated communication style is equivalent to social power where expectations are of a child's deference to the parent's wishes or values (McLeod and O'Keefe, 1972). The evidence in the literature indicates that the Family Communication Patterns (FCP) measures are adaptable to a consumption context by re-wording items (Rose et al., 1998).

The overall concept of Christmas request communication concerns parents' action or reaction to their children's requests for gifts. The concept orientation features parent's use of ideas and the 
socio orientation suggests communication of rules when discussing Christmas requests with their children. These communication patterns relate to Christmas request activities that encourage children to generate ideas about gift ideas and preferences or enforce parental rules and curtailment of request behaviors. In a Christmas request context, the borrow-modified adaptation of the traditional FCP (Table I) retains the intent of the concept-orientation but uses the name of ideas orientation because the focus is on those positive elements of social or decision-making skills. An ideas orientation suggests that the appropriate dimension theme is "it is your gift, you make the decisions." The use of Child's Decision encompasses the freedom of request choice for children and the unconditional endorsement by the parent that the request is a suitable Christmas gift. The other ideas orientation is freedom of expression by the child where parents seek advice on Christmas gifts and Christmas celebration activities within a framework of "what do you think." This orientation is Child's Advice and reflects the parent's acceptance of the child's input or advice. Socio-orientated communication is equivalent to social power and the name of the rules orientation applies because expectations are that a child should follow the parental wishes or values. In a Christmas context, the rules-orientation holds a theme of limiting or rejecting children's Christmas gift requests and an appropriate title would be Limit Requests. The second rules orientation has a theme of disagreement or quizzing children's gift requests and challenges children to defend or question the value of their request. The appropriate title becomes Quiz Requests.

Rose et al. (2002) strongly support the use of the concept and socio-communication rather than the four individual communication factors. A concept orientation comprises the pluralistic and consensual communication where the pluralistic theme allows the children to make their own decisions and the consensual theme solicits opinions. Children learn, decide or buy for themselves and help, advise or offer opinions to parents on consumption occasions. On the other hand, the socio orientation underscores a protective theme of parental regulation, control, prohibition or limitation through not allowing children to buy or do certain things and exhibit the cold indifference 
of the laissez faire style (Carlson et al., 1990). Consequently, the concept orientation becomes

Request Ideas and the socio-communication attracts the title of Request Rules.

\section{Take in Table I}

\section{Method}

The study here is a part of a larger Christmas gift giving study where the required information was gathered from the respondents via a self-administered survey method. The focus of the study is on parents, the sample frame is a parent with at least one child between the ages of three and eight years, and this designated age span appears in previous parent-child sample criteria (Rose et al., 1998). The literature features a number of studies (eg Macklin, 1996, Peracchio, 1992) that used kindergarten or primary school children in grades $2 ; 3 ; 4 ; 5$ (age spans 4 to 12 years) as sources for respondents in parent-child research. The estimation of the sample size for this study was based on the knowledge that response rates to mail surveys was typically less than 15\% (Malhotra et al., 2002). Additionally, past research has shown that school principals expect a 30 to 40 percent response rate for school distribution as being acceptable (Carlson and Grossbart, 1988) and response rates generally vary from $20 \%$ upwards (e.g. Kim and Lee, 1997, Hogg et al., 1998). During the month of November, a survey questionnaire package containing one instrument each for the parents (of 70 questions per instrument), instructions and a self-addressed return envelope was delivered to five participating schools and seven kindergartens for children to take home to their parents. There were 463 surveys returned of which 450 individual cases were suitable for analysis at an average return rate of $17.6 \%$. Anonymity meant follow-ups were not possible and the approach applied to data validation excluded those returns that contained full pages of unanswered questions.

\section{Measurement development}

Initially described as a child's view of communication interaction (Moschis and Churchill, 1978), the concept transferred to communication by mothers with their children (Moschis et al., 1984). 
While the measure items and content related to FCP may vary, the essential theme of parents discussing, socializing or instructing their children about consumption behaviours remains stable. These central themes reside in Carlson et al. (1990) and Carlson et al., (1994), however Rose et al. (1998) contained additional context-relevant items regarding purchase behaviours of children. Since the study here relates to request behaviour, a conscious decision was made to adapt the original items of Carlson et al. (1990) and Carlson et al. (1994) to a Christmas request context. Some Christmas request communication items in a pilot study contained references to Santa Claus. Clark (1995) refers to an anti-Santa sentiment and a number of comments that related to this phenomenon emerged from the pilot study. One of the comments was from a mother of three children who simply stated, "We don't talk about Santa a lot." Another comment explained a similar view:

"I'd like to have had one question about what I tell my child about Santa - I'm not sure that everyone tells the same story. For example, my son has been told that we buy his gifts and Santa delivers them \& that Santa only gives to those who are needier than us!"

It appeared that any mention of Santa Claus could distract the respondents and therefore an antiSanta bias could the taint data. Subsequently, the phrase "for Christmas" was substituted for "from Santa" in the relevant questions to negate the anti-Santa feeling.

In the first part, of a two part of the process, the data were entered, cleaned and subjected to an Exploratory Factor Analysis (EFA). Such an approach enables an observation and comparison of results from previous studies in terms of factor structure and reliabilities. The second step employs a confirmatory factor analysis (CFA) because CFA explicitly tests predetermined factor structures to confirm if the number of factors, and the loadings of measured indicator variables, conforms to expectations based on pre-established theory. The à priori assumption is that each factor is associated with a specified subset of indicator variables (Roberts, 1999), and FCP measures offer valid outcomes across different contexts. In essence, CFA seeks to determine if such measures of a latent variable really belong together. 


\section{Results}

There were 271 female and 179 male respondents where the age of the female respondents ranged from 24 to 59 and that of the males was from 27 to 55 years. Overall, $32.7 \%$ of respondents were 36 years of age or younger, $35.8 \%$ between 37 and 40 years and the older parents (over 41years) constituted $31.5 \%$ of the respondents. The household weekly income ranged from a minimum of $\$ 160$ up to $\$ 3000+$ per week where $30 \%$ of the sample had a combined income up to $\$ 1000$ per week, 55\% reported an income between $\$ 1000$ and $\$ 2000$; and $15 \%$ earned in excess of $\$ 2000$ per week. The dominant family structure was male, female parents and two children (average age of 5 years, 6 months). The sample provided a broad range of parental age, incomes and age of children that cover different performance rituals and Christmas activities.

The items addressing Christmas request communication represent a borrowed-modified source from the family communication patterns concept of Carlson et al. (1994). Some additional steps were required in the factor analysis to account for cross loading items to produce an 11 item, four factor structure for Christmas request communication construct. Table II shows the mean and standard deviations as well as the factor analysis for Christmas request communication. The dependability and consistency within a factor structure is assessed by Cronbach's Alpha reliability measure where a satisfactory level of reliability is dependent on how a measure is being used (Nunnally, 1967). There are different levels of reliability appropriate to applied, basic or exploratory research; applied research demands levels in excess of 0.90 . Achieving basic research reliabilities above the 0.80 level may be time consuming to administer and score (Nunnally, 1967), and there is a conventional rule of thumb that a level of 0.70 is generally satisfactory (Smith and Barclay, 1997). However, in exploratory research, a level of 0.60 is an acceptable minimum (Hair et al., 1998).

Alpha reliabilities around 0.50 to 0.60 are reported within the marketing literature generally and therefore, acceptable for this study. Carlson et al. (1994) reported an alpha of 0.56 for the 6-item, socio-orientation scale related to mothers' marketplace behaviors. Other reported reliability coefficients include 0.55 (Eastlick and Lotz, 2000), a range of 0.59 to 0.67 (Richins and Dawson, 
1990) and 0.49 for a two-item factor (Summers and McColl-Kennedy, 1995). Words, item-level statistics, reliability and factor analysis estimates will change from sample to sample as items are added or deleted from scales (Summers and McColl-Kennedy, 1995). Therefore, following the stance by Eastlick and Lotz (2000), a decision was made to retain the child's decision and the quiz requests items. This retention was because low reliabilities have been reported in previous family communication research (Carlson et al., 1994) and the items appear to have face validity. The twoitem factor also contributes to the overall structure and reliability of the Christmas request communication construct.

Take in Table II

The percentage of variance explained is at a level of $56.9 \%$, and the Christmas request communication measure has an adequate, overall reliability of 0.64 . The limiting request factor has the lowest mean of 2.77 and a standard deviation of 1.44 , while the other 3 factors have means between 4.64 and 5.00 and held similar standard deviations. While mothers dominate the Children's Advice and Quiz Requests dimensions, there is no significant difference between fathers' and mothers' use of these two dimensions. Mothers also prevail in the Childs Decision but there is a significant difference between mothers' and fathers' reliance on children deciding on their gift preferences ( $\mathrm{t}=-2.81$, df 448, Chi Sq 0.005). Although there is no significant difference between mothers' and fathers' use of the Limiting Requests, fathers appear to dominate this dimension. A composite variable for ideas request communication is formed through the combination of the child's decision and the child's advice factors; the mean of this request ideas variable was calculated at 4.82 with a standard deviation of 0.96 . The rules orientation combined rejecting and limiting requests and had a mean of 3.73 and a standard deviation of 1.01. Christmas request communication about ideas and rules expect to be distinct constructs and, at this preliminary stage, a correlation of 0.25 indicates a low relationship between the two items. 


\section{Confirmatory Factor Analysis}

The level and structure of the EFA results invoked a decision to investigate the factor structure and necessitated the use of CFA. Previous knowledge of theory and research provided both the variables and the factor structure and thus constitutes a pre-condition for CFA. A first order, confirmatory factor analysis examined the themes of concept orientation and socio-orientation using the original thirteen item statements. The concept orientation relates to input from children and the socio-orientation concerns parental imposition. The Request Ideas theme consists of 5 child's decision and 3 child's advice items; the Request Rules theme has two limit items and three quiz items.

A CFA seeks a non-significant model, however, when presented with a significant model, a number of fit indices come into consideration. Modification is required to obtain a better-fitting, parsimonious model and a series of modifications provided a better fit of the factor items. Although modifying a factor model means some fundamental change in meaning, a well performing model should maintain theoretical consistency rather than sample-dependent re-specification. The results indicate that the model is significant (Chi-square, 148.51; $\mathrm{DF}=61 ; \mathrm{P}=.000$ ), however, the fit indices indicate an valid, operative model (GFI .95; AGFI .93 and RMSEA .057).

A standardized estimates approach identifies the links between items and represents a correlation coefficient with a level of redundancy apparent between some items. In Figure I, a correlation of 0.37 is evident between Decisions about gift giving and deciding what they really want; such a pairing is appropriate because children's gift decisions are about them and their desires. A lower correlation (0.28) exists between Decisions about gift giving and advice for other family members and departs from the child's focused interest to include decisions about others and what they would like. Although these three items are related, the relationships are not of great consequence to warrant removal. Within the Rules theme, a low correlation (0.20) is apparent between the variables of Not allowed to request certain gifts and limit them to certain gifts. Finally, the 
relationship the request ideas and request rules come together with a strong correlation coefficient of 0.67 .

\section{Take in Figure $I$}

\section{Discussion}

This study adopted the view of Rose et al. (2002), who advocated that FCP should be treated as a bi-dimensional structure of concept and socio-orientation. The request ideas theme dominates Christmas request communication and highlights the request tradition of the parent-child relationship where parents welcome, expect or seek many requests from their children. There appears to be a moderate acceptance by parents of seeking advice; this component reflects comments by McNeal (1992) about the integration of children's responsibility and input into the family decision fabric. However, the moderate mean for request ideas overall, suggests that parents are blasé about children's request ideas, and reflect the various observations that parents are neutral or put off any commitment to requests, either way, around half of the time. Given the positive, cooperative elements of the ideas theme, the socio-orientation translates into a request rules theme of one-sided, adult directed rules of limiting or quizzing requests constructs. Parents appear to be not concerned with limiting children's requests, but are moderately inclined to quiz children about the appropriateness of their request and where they got ideas for those requests. The composite mean for the request rules construct suggests a similar non-commitment by parents to that of request ideas.

Although the reliabilities are below those reported in the literature, the overall request communication construct has face validity and the reliability is at an acceptable level. This study maintains an evident trend in the FCP literature (Carlson et al., 1994, Tims and Masland, 1985), where the application of the concept orientation items continues as a reliable measure, while the socio-orientation measure demonstrates a weakness of low reliability. 
One value of the CFA approach identifies similarities between statements. In the Request Ideas construct items relating to children's gifts and gifts for others are associated. Gift receiving and giving are important and critical components of relationship development and Christmas is an opportune time for parents to encouragement of decision criteria and evaluation processes that prepare children for decisions later in life. Children's gift decisions as to desires and evaluations are about them and the advice for other family members extends to decisions about others and the encouragement of giving over receiving. Parents set rules of request exclusion by simply stopping or denying requests for particular gift; maybe, to engender respect for others or control excessive or inappropriate items as gifts. Therefore, a more fully described, parsimonious model becomes apparent through the inclusion of all thirteen items in the CFA and supports claims that use of a CFA should prevail over exploratory techniques (eg Roberts, 1999). The results for both the EFA and CFA reinforce the concept that parents encourage individualism in their children's request behavior, but an acceptable request should reflect parental values, standards and control.

Although both request ideas and request rules are strongly correlated contributors to Christmas request construct, the results reflect a parent's apparent indifference to children's request behavior. Ultimately, parents have the greater resources within the family and therefore have the greater influence over the final decision (Spiro, 1983). However, inherent in communication around Christmas is the discussion about the extra-ordinary topics of gift suitability, brands, availability and prices. If a Christmas gift request is a form of influence, then parents react by acceding, deferring or negating the request rather than exploring the elements or characteristics of the requested gift. Alternately, if Christmas requests are an expression of preference (Isler et al., 1987), then parents would search for relative information to counter or confirm the suitability or availability of the gift request. On the other hand, they may not discuss these activities in depth because parents try to maintain an element of surprise.

The request tradition, together with the essence of marketplace family communication patterns, allows children the freedom of choice to evaluate the style, type or brand of their Christmas gift 
request. On the other hand, some children may be too young to understand the request traditions and communication with these children resides in socialization issues rather than requests. Hence, gifts for some children are simply a pretty doll or a big truck and there would be minimal use of information sources by parents other than finding such nondescript gifts. Other children may be more knowledgeable to request substantial gifts or brands and they would be able to contribute relative information about costs or availability as part of the request; they do so with catalogues that contain illustrations, prices and availability. These styles and the content of such exchanges are representative of the two-way interactions that are part of family communications at Christmas. Parents encourage a positive exchange of desire and opinion from children because parents seek advice on presents for the children and other family members. Parents also set boundaries for gift requests by denying certain gifts and limiting the style of gifts. Overall, parents appear to condone an atmosphere of requests and aspirations because the limiting of gift requests through direct parental instruction is a minimal, yet complimentary element of request behaviour.

\section{Key Limitations and Future Research}

Because Christmas is the peak of consumption and gift giving in Christian, western-style societies, the initial limitation related to the context of gift giving at Christmas in Australia. While Christmas giving between family and friends dominates the literature, the key limitation lays in the use of the sample frame of parents of 3 - 8 year-old children because, at this age, parents generally engage in the Santa Claus myth and the associated request behavior of their children. Another limitation related to the sample population as it was located within urban and semi-rural areas and thus exposed to a high level of promotion and catalogues, together with a high number of competitive retailers. Other constraints such as financial, cultural or regional influences may influence the discussions about Christmas gifts and thus presents both a limitation and an area of future research.

This research has highlighted two opportunities for future research. The first is for additional theory development because perennial adaptation of the family communication measures appears to weaken the reliability of the measures when removed from the original intent and meaning. In 
addition, this study confirms the claim that use of a CFA should prevail over exploratory techniques when factor structures are already known (eg Roberts, 1999) and a better fitting model emerges. The second outcome is the scope to develop a deeper understanding of parental Christmas communication. Understanding this interaction has implications for producers, brand owners and advertisers. Caplow (1984) suggests that when young children are no longer resident in the house, there is no need for a Christmas tree. If a ritual undergoes such changes, then the level and content relating to Christmas communication would change. Hence, the gift exchange relationship between parents and their children matures as the Santa myth dissipates. Therefore, another view worthy of future research features the communication patterns and intent through stages such as mid teens or early adulthood.

\section{Conclusion}

Christmas and gift giving research continues to mature and develop both theoretically and empirically. While the literature examines Christmas as an occasion, no research explores parental responses to their children's request behavior and this article is a journey of exploration that establishes the basis for a theoretical understanding of the way parents interact with their children as part of the Christmas gift request ritual. As such, this research identified and defined parental communication about Christmas request behavior in simple terms of request ideas and request rules.

The research here combines elements of the broad consumer behavior literature and attempts to remedy the shortcomings in the literature concerning the complex inter-related phenomenon of parental gift giving at Christmas. The study sets a basis for future inquiry into Christmas communication in general and gift requests in particular.

\section{Implications for Business}

Understanding and capitalizing on the interactions between parents and children holds importance for practitioners associated with children's products and brands as well as adult brands that move into the child's domain. Research indicates that parents appear to deny, ignore or discourage 
requests by children throughout the year, but they treat Christmas as a special occasion and willingly encourage request behaviour from children. The ritual of Christmas requests suggests that parents are inviting the child into an information exchange scenario. While they talk with their children about gift ideas and preferences, parents become aware of the existence of new products or brands. Recipients contribution to the gift giving act is important, consequently, the traditional advertising to children strategy style at least allow children to form preferences and then inform parents as part of a reverse socialization concept. In essence, advertising toys to children creates awareness and desire that manifests either as an earnest request at Christmas or perceived as the Pester Power syndrome that creates, in parents, negative attitudes towards induced behaviors, products and brands.

Because Christmas gift decisions require comparison of product attributes and incorporate complex decision processes, parents seek and accept information relevant to their values and reasoning behind their gift decisions. In most instances, owners, advertisers and managers follow the belief that toys are the sole domain of children. However, parents still make the final gift decisions and invoke their own values and beliefs about the rearing of their children, and the gifts they receive. If parents hold favorable, prior knowledge then they may respond positively and nominally approve (or promote) the gift as being suitable. Having minimal or non-existent knowledge could generate negativity and dismissal of that specific brand. However, parents bond with their children by coviewing television or going to the movies where character promotion and product placement accentuates, confirms or recalls childhood experiences. If the parent enjoys the movie and the characters, then such shared positive experiences and knowledge reflect in any gift request considerations.

The use of traditional advertising strategies that encourage children to "ask Mom" may not be effective in a one-chance, Christmas gift situation. The problem for managers is to inform parents about products and brands in terms that appeal to parents and their nurture or protective values. 


\section{References}

Baumrind, D. (1968) "Authoritarian vs. Authoritative Parental Control" Adolescence, Vol. 3, pp 255-272.

Baumrind, D. (1989) "Rearing competent children" In Child Development Today and Tomorrow (Ed, Damon, W.) Jossey-Bass Publishers, San Francisco, pp. 349-377 Chapter 17.

Becker, W. C. (1964) "Consequences of different kinds of parental discipline" In Review Of Child Development Research V.1 (Eds, Hoffman, M. L. and Hoffman, L. W.) Sage, New York.

Belk, R. W. (1987) "A Child's Christmas in America: Santa Claus as Diety, Consumption as Religion" Journal of American Culture, Vol. 10, pp 87-100.

Belk, R. W. (1989) "Materialism and the modern U.S. Christmas" In Interpretive Consumer Research (Ed, Hirschman, E.) Association for Consumer Research, Provo UT, pp. 115-135.

Caplow, T. (1984) "Rule enforcement without visible means: Christmas gift giving in Middletown" American Journal of Sociology, Vol. 89(6), pp 1306-1323.

Carlson, L. and Grossbart, S. (1988) "Parental style and consumer socialization of children" Journal of Consumer Research, Vol. Vol. 15 (1), pp 77-94.

Carlson, L., Grossbart, S. and Tripp, C. (1990) "An investigation of mothers' communication orientations and patterns" In Advances in Consumer Research, Vol. 17 (Eds, Goldberg, M., Gorn, G. and Pollay, R.) Association for Consumer Research, Provo UT, pp. 804-812.

Carlson, L., Walsh, A., Laczniak, R. N. and Grossbart, S. (1994) "Family communication patterns and marketplace motivations, attitudes, and behaviors of children and mothers" The Journal of Consumer Affairs, Vol. 28 Number 1, pp 25-53.

Caron, A. and Ward, S. (1975) "Gift decisions by kids and parents" Journal of Advertising Research, Vol. 15, pp 5-20.

Clark, C. D. (1995) "Flights of Fancy, Leaps of Faith: Children's Myths in Contemporary America", The University of Chicago Press, Chicago.

Downs, A. C. (1983) "Letters to Santa Claus: Elementary school-age children's sex-typed toy preferences in a natural setting" Sex Roles, Vol. 9, pp 159-163.

Easterling, D., Miller, S. and Weinberger, N. (1995) "Environmental consumerism: A process of children's socialization and families' resocialization" Psychology and Marketing, Vol. 12, pp 531-550.

Eastlick, M. A. and Lotz, S. L. (2000) "Objective and multidimensional acculturation measures: Implications for retailing to Hispanic consumers" Journal of Retailing and Consumer Services, Vol. 7 (3), pp 149-160.

Ekstrom, K. M., Tansuhaj, P. S. and Foxman, E. R. (1987) "Children's influence in family decision and consumer socialization: A reciprocal view" In Advances in Consumer Research, Vol. 14 (Eds, Wallendorf, M. and Anderson, P.) Association for Consumer Research, Provo, UT, pp. 283-287.

Foxman, E. R., Tansuhaj, P. S. and Ekstrom, K. M. (1989) "Family members' perceptions of adolescents' influence in family decision making" Journal of Consumer Research, Vol. Vol. 15 (4), pp 482-491.

Grotevant, H. D. (1989) "Child development within the family context" In Child Development Today and Tomorrow (Ed, Damon, W.) Jossey-Bass Publishers, San Francisco, pp. 34-51 Chapter 2. 
Gunter, B. and Furnham, A. (1998) "Children as Consumers: A Psychological Analysis of the Young People's Market", Routledge, London.

Hair, J. F., Anderson, R. E., Tatham, R. L. and Black, W. C. (1998) "Multivariate Data Analysis with Readings", Prentice-Hall, New Jersey.

Hill, C. F. and Romm, C. T. (1996) "The role of mothers as gift givers: A comparison across three cultures" In Advances in Consumer Research, Vol. 23 (Eds, Corfman, K. and Lynch, J.) Association for Consumer Research, Provo UT, pp. 21-29.

Hogg, M. K., Bruce, M. and Hill, A. J. (1998) "Fashion brand preferences among young consumers" International Journal of Retail \& Distribution Management, Vol. 26, pp 293300 .

Isler, L., Popper, E. T. and Ward, S. (1987) "Children's purchase and parental responses: Results from a diary study" Journal of Advertising Research, Vol. Vol. 27(5), pp 28-39.

Kim, C. and Lee, H. (1997) "Development of family triadic measures for children's purchase influence" Journal of Marketing Research, Vol. 34 (3), pp 307-321.

Labrecque, J. and Ricard, L. (2001) "Children's influence on family decision-making: A restaurant study" Journal of Business Research, Vol. Nov; Vol 54(2), pp 173-176.

Lackman, C. and Lanasa, J. M. (1993) "Family decision-making theory: An overview and assessment" Psychology and Marketing, Vol. Vol. 10 (2):, pp 81-93.

Laible, D. J. and Thompson, R. A. (2000) "Mother-child discourse, attachment security, shared positive affect, and early conscience development" Child Development, Vol. 71, pp 14241440 .

Macklin, M. C. (1996) "Preschoolers' learning of brand names from visual cues" Journal of Consumer Research, Vol. Vol. 23 (3), pp 251-261.

Malhotra, N., Hall, J., Shaw, M. and Oppenheim, P. (2002) "Marketing Research: An Applied Orientation".

McLeod, J. M. and O'Keefe, G. J. (1972) "The socialization perspective and communication behavior" In Current Perspectives in Mass Communication Research (Eds, Kline, F. G. and Tichenor, P. J.) Sage, Beverly Hills [Calif.].

McNeal, J. U. (1992) "Kids as Customers : A Handbook of Marketing to Children", Lexington Books, New York.

Moschis, G. P. and Churchill, G. A. (1978) "Consumer socialization: A theoretical and empirical analysis" Journal of Marketing Research, Vol. 15 (4), pp 599-609.

Moschis, G. P., Moore, R. L. and Smith, R. B. (1984) "The impact of family communication on adolescent consumer socialization" In Advances in Consumer Research, Vol. 11 (Ed, Kinnear, T. C.) Association for Consumer Research, Provo UT, pp. 314-319.

Nunnally, J. C. (1967) "Psychometric Theory", McGraw-Hill, New York.

O'Cass, A. and Clarke, P. (2002) "Dear Santa, do you have my brand? A study of the brand requests, awareness and request styles at Christmas time" Journal of Consumer Behaviour, Vol. September Vol.2, pp 37-53.

Otnes, C., Kim, Y. C. and Kim, K. (1994) "All I want for Christmas: An analysis of children's brand requests to Santa Claus" Journal of Popular Culture, Vol. Spring, v27, pp 183-195.

Palan, K. M. (1998) "Relationships between family communication and consumer activities of adolescents: An exploratory study" Journal of the Academy of Marketing Science, Vol. 26, pp 338-349. 
Peracchio, L. A. (1992) "How do young children learn to be consumers? A script-processing approach" Journal of Consumer Research, Vol. Vol. 18 (4), pp 425-440.

Pollay, R. W. (1987) "It's the thought that counts: A case in Xmas excesses" In Advances in Consumer Research, Vol. 14 (Eds, Wallendorf, M. and Anderson, P.) Association for Consumer Research, Provo UT, pp. 140-143.

Richardson, J. G. and Simpson, C. H. (1982) "Children, Gender, and Social Structure: An Analysis of the Contents of Letters to Santa Claus." Child Development, Vol. Apr Vol 53, pp 429436.

Richins, M. L. and Dawson, S. (1990) "Measuring material values: A preliminary report of scale development" In Advances in Consumer Research, Vol. 17 (Eds, Goldberg, M., Gorn, G. and Pollay, R.) Association for Consumer Research, Provo UT, pp. 169-175.

Roberts, J. K. (1999) "Basic Concepts of Confirmatory Factor Analysis", In Annual Meeting of the Southwest Educational Research AssociationSan Antonio, TX.

Roberts, M.-L., Wortzel, L. H. and Berkeley, R. L. (1981) "Mothers' attitudes and perceptions of children's influence and their effect on family consumption" In Advances in Consumer Research, Vol. VIII (Ed, Monroe, K.) Association for Consumer Research, Ann Arbour MI, pp. 730-735.

Rose, G. M., Boush, D. and Shoham, A. (2002) "Family communication and children's purchasing influence: A cross-national examination" Journal of Business Research, Vol. Volume 55, pp 867-873.

Rose, G. M., Bush, V. D. and Kahle, L. (1998) "The influence of family communication patterns on parental reactions toward advertising: A cross-national examination" Journal of Advertising, Vol. 27, pp 71-85.

Sherry, J. F. (1983) "Gift giving in anthropological perspective" Journal of Consumer Research, Vol. Vol. 10 (2), pp 157-168.

Smith, J. B. and Barclay, D. W. (1997) "The effects of organizational differences and trust on the effectiveness of selling partner relationships" Journal of Marketing, Vol. 61, pp 3-21.

Spiro, R. L. (1983) "Persuasion in family decision making" Journal of Consumer Research, Vol. Vol. 9 (4), pp 393-402.

Summers, J. M. and McColl-Kennedy, J. R. (1995) "Development of a measurement scale for analysing destination choice criteria in the tourist decision process" In European Advances in Consumer Research, Vol. 2 (Ed, Hansen, F.) Association for Consumer Research, Provo UT, pp. 406-411.

The NPD Group Inc (2006) The NPD Group reports on 2005 U.S. Toy industry sales, Press Release, February 13, 2006, available http://www.npd.com/dynamic/releases/press_060213.html [Accessed 2006, 19 September]

Tims, A. R. and Masland, J. L. (1985) "Measurement of family communication patterns" Communication Research, Vol. 12, pp 35-57. 


\section{Table I Item Statements - Christmas Request Communications}

\begin{tabular}{l} 
Carlson \& Grossbart 1994 \\
\hline Concept Orientation \\
Make own decisions \\
I tell my child to decide about things he/she \\
should or shouldn't buy \\
I tell my child to decide how to spend his / her \\
money \\
I tell my child buying things he/she likes is \\
important even if others don't like them \\
To teach my child to become a consumer, I allow \\
my child to learn from his / her own experience
\end{tabular}

\section{Solicit Opinions}

I ask my child to help me buy things for the family

I ask my child for advice about buying things

I tell my child what he/she thinks about things he/she buys for him / her self

\section{Socio-orientation}

\section{Exert Control}

I tell my child what things he / she should or shouldn't buy

I tell my child he/she is not allowed to buy certain things

I complain when I do not like something my child brought for him/herself

To teach my child to become a consumer, I stop my child from doing certain things

\section{Cold Indifference}

I tell my child he/she shouldn't ask questions about things children do not usually buy

I want to know what my child does with his / her money
Christmas Adaptation

\section{Request Ideas}

\section{Child's Decision}

I tell my children to decide about the sort of gifts that they really want for Christmas.

I tell my children to decide about things they should or should not request as a gift for Christmas.

I tell my children to request the sort of gifts that are really important to them, even if their friends don't like that sort of product or brand

To teach my children to become consumers, I allow them to learn from their choice experiences.

\section{Child's Advice}

I ask my children to help with the decisions about gift giving at Christmas.

I ask my children for advice about gifts for other family members at Christmas.

I ask my children what they think about the gifts that they request for Christmas.

\section{Request Rules}

\section{Limit Requests}

I tell my children the sort of presents that they will get for Christmas.

I tell my children that they are not allowed to request certain gifts for Christmas.

I disagree with my children when I do not like some of the products or brands that they request as gifts for Christmas.

To teach my children to become consumers, I limit them to asking for certain types of products or brands as gifts.

\section{Quiz Requests}

I tell my children that they should not ask questions about the Christmas gifts that I buy.

I want to know where my children get the ideas for their requests. 
Table II Factor Structure - Christmas Request Communication

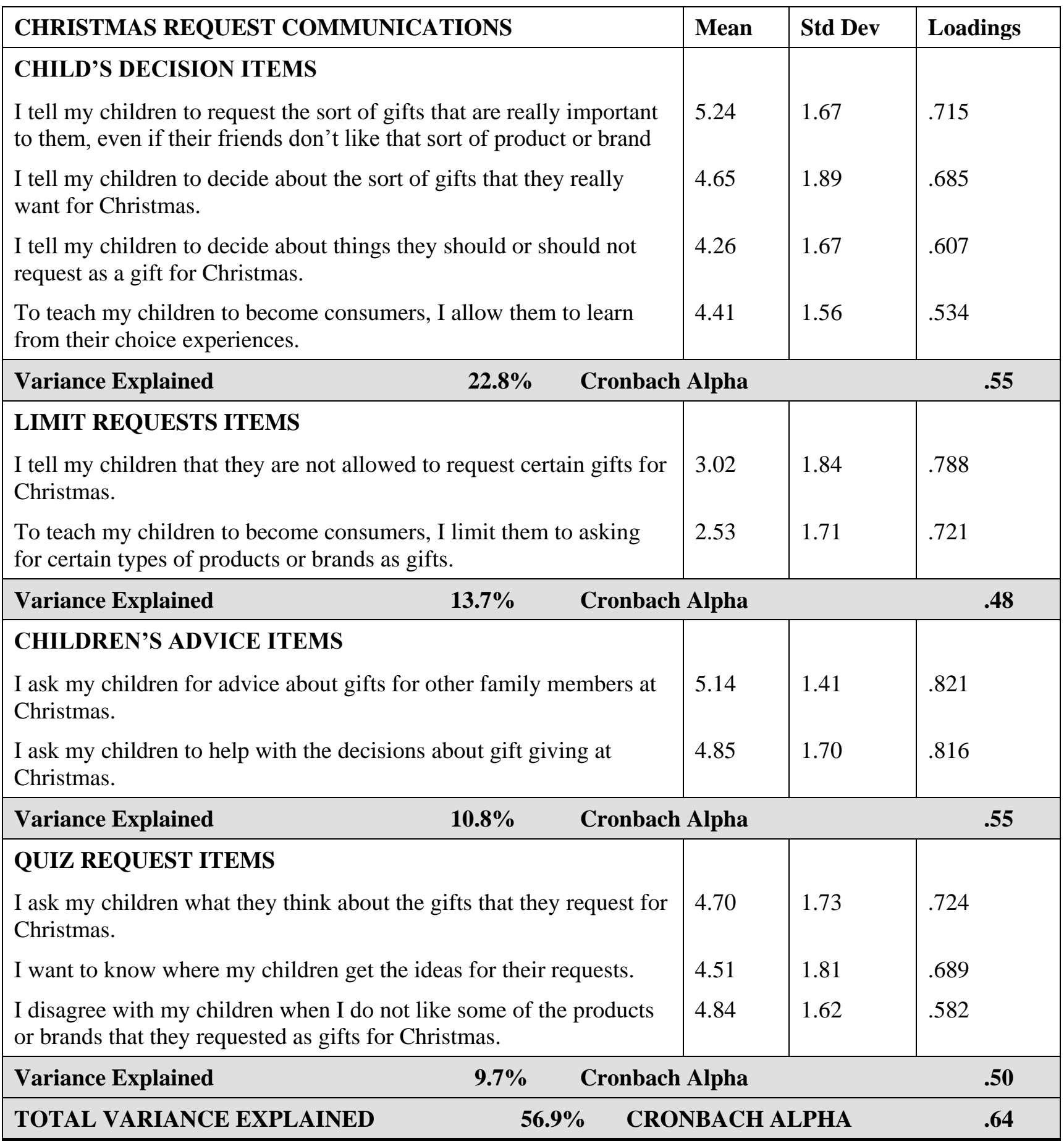


Figure I Confirmatory Factor Analysis Diagram
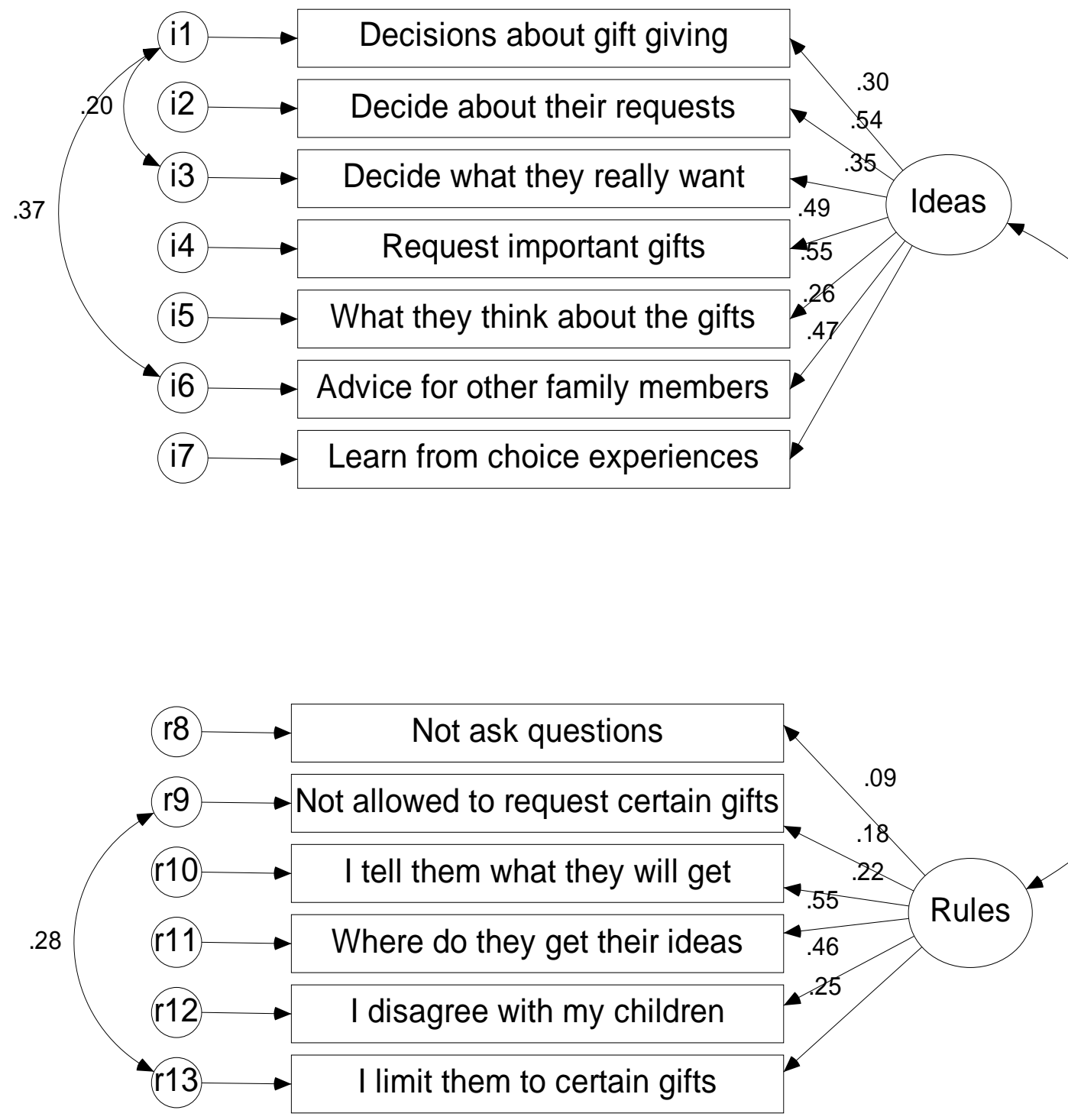